\title{
Feasibility of a novel vermitechnology using vermicast as substrate for activated sludge disposal by two epigeic earthworm species
}

\author{
Kui Huang ${ }^{1^{*}}$, Fusheng $\mathrm{Li}^{2}$, Xiaoyong $\mathrm{Fu}^{3}$, Xuemin $\mathrm{Chen}^{3}$ \\ ${ }^{1}$ Graduate School of Engineering, Gifu University, Gifu, Japan; *Corresponding Author: q3812102@edu.gifu-u.ac.jp \\ ${ }^{2}$ River Basin Research Center, Gifu University, Gifu, Japan \\ ${ }^{3}$ School of Environmental and Municipal Engineering, Lanzhou Jiaotong University, Lanzhou, China
}

Received 11 July 2013; revised 12 August 2013; accepted 1 September 2013

Copyright (C) 2013 Kui Huang et al. This is an open access article distributed under the Creative Commons Attribution License, which permits unrestricted use, distribution, and reproduction in any medium, provided the original work is properly cited.

\begin{abstract}
This study was conducted to investigate the feasibility of vermicomposting by using vermicast as the substrate for the stabilization of municipal activated sludge, called hereafter as direct vermistabilization, in which the pre-treatment and bulking materials required in previous practices were all omitted. For this purpose, two epigeic earthworm species, namely Eisenia foetida and Bimastus parvus, were inoculated into substrate for composting fresh dewatered activated sludge. Direct vermistabilization resulted in significant reductions in $\mathrm{pH}, \mathrm{TOC}, \mathrm{C} / \mathrm{N}$ ratio and the content of heavy metals, as well as increases in EC, total $N$, total $P$ and total $K$ in the final vermicast. Moreover, both Eisenia foetida and Bimastus parvus showed faster growth rate and higher cocoon production. The results of this study suggest that the direct vermistabilization has the advantages of being simple, cost-effective and efficient, and can thus be used as a feasible vermicomposting approach to convert fresh dewatered activated sludge into a valuable product for agricultural use. The results also suggest that Bimastus parvus can be used as a new potential candidate for vermicomposting of municipal activated sludge.
\end{abstract}

Keywords: Activated Sludge; Biology; Earthworms; Heavy Metals; Nutrients; Vermicomposting

\section{INTRODUCTION}

Large scale urbanization in recent years has resulted in the generation of large amount of municipal sewage slu- dge, which has become one of emerging environmental issues in the world. Currently, the primary means of sludge treatment include direct application for agricultures, landfill, incineration, and so on. According to the situations of developing countries, the use of sludge for agricultural purposes is probably the most appropriate method for its disposal. However, it is well known that municipal sludge is a complex waste that contains not only large amounts of organic matter and nutrient elements, but also many heavy metals and harmful organic pollutants and pathogens. Direct application of sludge as the fertilizer, without undergoing prestabilization treatment, may pollute agricultural lands and cultivated crops. It is thus necessary and urgent to seek ecologically sound technologies that enable sustainable recycling of rich nutrients and high organic content in municipal sludge, and at the same time, can ensure a significant reduction in the risk-causing hazardous substances.

Vermicomposting is a process for stabilization of organic waste materials through the joint involvement of earthworms and microorganisms. Microorganisms are responsible for biochemical degradation of organic matter contained in the waste materials; while earthworms play their roles as mechanical blenders and drivers of the process through modifying the biological, physical and chemical status, gradually reducing the $\mathrm{C} / \mathrm{N}$ ratio of organic matter, increasing the surface area attachable by microorganisms, and converting the waste materials into ones more favourable for microbial activity and further decomposition [1]. During the vermicomposting process, the important plant nutrients such as nitrogen, potassium, phosphorus and calcium present in the organic waste materials are converted into more available forms for plant growth [2]. Moreover, the worms themselves can serve as a protein source for animals' feeds [3]. For all these 
reasons, vermicomposting has been considered as an ecological and cost effective technology for the treatment and recycling of different organic waste materials, particularly for developing countries.

The use of earthworms in sludge management is termed as vermistabilization [4]. Recent studies have demonstrated that vermicomposting is highly useful and competitive for stabilization of activated sludge generated in sewage treatment plants [5-8]. However, intensive literature review revealed clearly that most previous studies on vermicomposting were conducted using batch systems, in which pre-treatment and/or bulking materials were used for improving the activities of earthworms and microorganisms. This makes the process much complicated when activated sludge is dealt with. So far, studies using continuous vermicomposting systems are very limited; and experimental approaches using vermicast as the substrate for improving the efficiency of vermicomposting, which may allow the omission of pre-treatment and the use of bulking materials, can be hardly found.

This study was aimed to evaluate the feasibility of direct vermistabilization by using vermicast as the substrate for composting of municipal activated sludge in continuous vermicomposting system. For this, Eisenia foetida, a worm species that has been commonly used in vermicomposting, was utilized. Meanwhile, for comparison and searching for new effective species, Bimastus parvus that has not yet been reported so far in existing literature was also investigated. The analytical items included the physicochemical properties of the end products of vermicast, and the growth and the fecundity of the earthworms during direct vermicomposting.

\section{METHODS}

\subsection{Earthworms and Municipal Activated Sludge}

Two species of epigeic earthworms (E. foetida and $B$. parvus), originally collected from the piles of cow dung in a local cattle farm, were randomly picked out for experimentation from individual stocking bin, respectively. The stock earthworms were cultured in the laboratory for one year by using biosolids (i.e., food waste, municipal sludge and cow dung) as the feed materials. The municipal activated sludge used in this experiment was obtained from the Lanzhou Wastewater Treatment Plant, Lanzhou, China. The characteristics of the sludge were: water content $=75 \%, \mathrm{pH}=7.82$, electrical conductivity $(\mathrm{EC})=0.46 \mathrm{~S} / \mathrm{cm}$, total organic carbon $(\mathrm{TOC})$ $=32.32 \%$, total nitrogen $(\mathrm{TN})=36.42 \mathrm{~g} / \mathrm{kg}$, total phosphorus $(\mathrm{TP})=7.70 \mathrm{~g} / \mathrm{kg}$, total potassium $(\mathrm{TK})=11.22$ $\mathrm{g} / \mathrm{kg}, \mathrm{C} / \mathrm{N}$ ratio $=9.72$, copper $(\mathrm{Cu})=210.00 \mathrm{mg} / \mathrm{kg}$, zinc $(\mathrm{Zn})=1557.67 \mathrm{mg} / \mathrm{kg}$, lead $(\mathrm{Pb})=68.42 \mathrm{mg} / \mathrm{kg}$, and chromium $(\mathrm{Cr})=125.68 \mathrm{mg} / \mathrm{kg}$.

\subsection{Experimental Design}

The experiment was conducted in perforated cylindrical plastic containers, each with a capacity of about $10 \mathrm{~L}$ (25 cm in diameter and $20 \mathrm{~cm}$ in height). The thickness of the substrate bedding was maintained at about $10 \mathrm{~cm}$ in all the containers throughout the experiment. The earthworms of $E$. foetida and $B$. parvus were introduced into individual containers, respectively, for acclimatization prior to the addition of sludge. Following one day's acclimatization, $700 \mathrm{~g}$ of the fresh dewatered sludge was directly added onto the substrate bedding. A control was also operated in parallel for investigation of the performance of degradation, for which worms were not introduced. All containers were kept in dark at the room temperatures $\left(22^{\circ} \mathrm{C}-28^{\circ} \mathrm{C}\right)$. The moisture content of the feed in each container was maintained at $70 \% \pm 10 \%$. To prevent moisture loss and avoid direct sunlight, all containers were covered with shade plastic bags and black burlap. For each experiment, three replicate were operated and the running time length was 30 days. Vermicomposting samples were collected at different times, i.e., 0,10 , 20 and 30 days, after each experiment was commenced.

\subsection{Chemical Analysis}

Physicochemical analysis was conducted on the dry weight basis. All chemicals used were of the analytical reagent grade. All samples were analyzed in triplicate and the results were averaged. $\mathrm{pH}$ and EC were measured with $1 / 10(\mathrm{w} / \mathrm{v})$ suspensions by using digital $\mathrm{pH}$ and EC meters (Systronic made), respectively. TOC was measured using the method of [9]. TN was measured using the Kjeldahl method. TP was measured using the molybdenum colorimetric method. The total concentrations of $\mathrm{K}, \mathrm{Cu}, \mathrm{Zn}, \mathrm{Pb}$ and $\mathrm{Cr}$ were quantified using ICP-AES (IRIS Intrepid II XSP, Thermo Elemental, America) after digesting the sample in the mixed acidic solution of $\mathrm{HNO}_{3}$ and $\mathrm{HClO}_{4}\left(\mathrm{HNO}_{3}: \mathrm{HClO}_{4}=4: 1, \mathrm{v} / \mathrm{v}\right)$.

\subsection{Statistical Analysis}

Statistical analysis was conducted using the Statistica Package (Version 8.0). ANOVA was performed to analyze the significance of the differences among the chemical properties at the significance level of 0.05 . For independent samples, t-test was performed between $E$. foetida and B. parvus for their biological differences.

\section{RESULT AND DISCUSSION}

\subsection{Changes in Nutrients Properties during Vermicomposting Process}

After 30 days of vermistabilization, the end products became much darker, more granular and homogeneous in 
appearance, and odour free. Table 1 shows variations of $\mathrm{pH}$ and EC during vermicomposting. Statistically significant decreases of $\mathrm{pH}$ with the vermicomposting time were observed for treatment with both worms $(p<0.001)$ as compared to the control; and a significant difference in the decreasing extent of $\mathrm{pH}$ between two worm species were also confirmed existent $(p<0.001)$. For instance, after 30 days of composting, $\mathrm{pH}$ with $E$. foetida was nearly neutral $(7.03 \pm 0.06)$, while that with $B$. parvus was slightly acidic $(6.20 \pm 0.20)$. This result supports previous ones obtained by others on vermicomposting of sludge $[5,6]$. The shift of $\mathrm{pH}$ during vermicomposting is probably due to mineralization of nitrogen and phosphorus into nitrites/nitrates and orthophosphates, respectively, and due to bioconversion of organic materials into intermediate species of organic acids [2]. The different decreasing extent of $\mathrm{pH}$ between $E$. foetida and B. parvus observed in the present study may indicate the speciesspecific differences of worms in their mineralization efficiency, for which further elaborative studies are required. In regard of the changes of EC during vermicomposting, the data shown in Table 1 revealed that EC increased gradually with time. Compared to the control beddings where earthworms were not introduced, the experimental beddings introduced with earthworms displayed a significant increasing trend $(p<0.001)$, with the value of EC being increased by approximately 4 folds. This increase was probably due to the loss of organic matter and the release of different mineral salts in available forms such as phosphate, ammonium and potassium [10]. Moreover, comparison of the EC values at all treatment times between the tested two earthworm species demonstrated less apparent difference $(p>0.05)$.

Changes of TOC and TN during vermicomposting are illustrated in Table 2. TOC reduced by about 30\% for the treatment with two earthworms as against the control treatment $(p<0.001)$. Significant differences between the tested two earthworms species were not confirmed ( $p$ $>0.05)$. The reduction in TOC during vermicomposting observed in the present result is consistent with previous reports that earthworms can accelerate decomposition and mineralization of organic matter contained in sludge $[5,11,12]$. The loss of carbon, in the form of $\mathrm{CO}_{2}$, was probably the result of earthworms' roles in enhancing the activity of decomposers, e.g. bacteria, fungi, nematode and protozoa, populated in the vermicomposting system, as reported by [7]. The conversion of some organic fractions of the waste into the earthworm biomass was also a likely reason leading to the observed carbon reductions [5-7]. In contrary to the decreasing trend of TOC, the content of TN increased by approximately 30\% through vermicomposting ( $p<0.001$ ); and no significant differences were found between the tested two earthworm species $(p>0.05)$. The results of the present study are supported by the previous ones documented [13,14]. It was postulated that earthworms can enhance nitrogen levels by adding their excreta, mucus, body fluid and enzymes, etc. into the substrate; moreover, the decaying tissues of dead worms also add a significant amount of nitrogen into the vermicomposting system [14].

The $\mathrm{C} / \mathrm{N}$ ratio of organic materials reflects the extent of mineralization and stabilization during the process of composting or vermicomposting. As shown in Figure 1, the $\mathrm{C} / \mathrm{N}$ ratio decreased by $47.3 \%$ in the earthworm treatment systems, which is much higher than in the control $(p<0.001)$; and the differences between the tested two earthworm species were insignificant $(p>0.05)$. The final $\mathrm{C} / \mathrm{N}$ ratios of the vermicast, i.e., the vermicast after treatment for 30 days, by $E$. foetida and B. parvus descended to 5.16 and 5.08, respectively. The decrease in $\mathrm{C} / \mathrm{N}$ is probably a combined effect of the loss of carbon as carbon dioxide due to microbial respiration and of the simultaneous addition of nitrogen by earthrms in the form of mucus and nitrogenous excretory materials during vermicomposting, as suggested by [8]. Compared to previous studies, in which some bulking materials, such as cow dung, straw and compost, were added into sludge before vermicomposting $[5,6,13,14]$, although the $\mathrm{C} / \mathrm{N}$ ratio in the material (activated sludge) of the present study was lower, apparent decreases of its value in the treatment systems with earthworms were still observed. This may thus suggest that a greater extent of organic matter stabilization of municipal activated sludge was achieved through vermicomposting even if no bulking materials and pre-treatment were employed.

The changes in TP and TK during vermicomposting of activated sludge are shown in Table 3 . The content of TP was significantly higher in the treatment systems with $E$. foetida $(12.53 \%)$ and B. parvus $(9.10 \%)$ than in the control $(p<0.001)$, with the increasing extent being less dependent on the earthworm species $(p>0.05)$. The observed result of increases in $\mathrm{P}$ during vermicomposting is consistent with the findings of others $[5,8]$ and was probably due to mineralization of organic phosphorous. According to Lee (1992) [15], the passage of organic matter through the gut of earthworms could convert phosphorus into forms much more available to plants. In another study, Le Bayon and Binet (2006) [16] conuded that the impact of earthworms on the biogeochemical transformation of phosphorus in soils depends on the close relationship between the properties of the organic phosphorous sources and the specific burrowing behaviour and food preferences of worms. For the total potassium, a gradual increase of TK with time was also observed (Table 3). Statistically, the increases in the content of TK in the treatment systems with earthworms (by up to 9.8\%) was significant than in the control $(p<0.001)$. Nevertheless, the difference of TK between two worm species was 
Table 1. Changes of $\mathrm{pH}$ and EC during vermicomposting of activated sludge.

\begin{tabular}{|c|c|c|c|c|c|c|}
\hline \multirow{3}{*}{ Days } & \multicolumn{3}{|c|}{$\mathrm{pH}$} & \multicolumn{3}{|c|}{$\mathrm{EC}(\mathrm{S} / \mathrm{cm})$} \\
\hline & \multirow{2}{*}{ Control } & \multicolumn{2}{|c|}{ Vermicomposting } & \multirow{2}{*}{ Control } & \multicolumn{2}{|c|}{ Vermicomposting } \\
\hline & & E. foetida & B. parvus & & E. foetida & B. parvus \\
\hline 0 & $7.83 \pm 0.06$ & $7.83 \pm 0.06$ & $7.83 \pm 0.06$ & $0.46 \pm 0.04$ & $0.46 \pm 0.04$ & $0.46 \pm 0.04$ \\
\hline 10 & $7.57 \pm 0.04$ & $7.43 \pm 0.06$ & $7.25 \pm 0.05$ & $0.52 \pm 0.03$ & $0.78 \pm 0.02$ & $0.70 \pm 0.02$ \\
\hline 20 & $7.50 \pm 0.03$ & $7.13 \pm 0.05$ & $6.71 \pm 0.15$ & $0.58 \pm 0.02$ & $1.79 \pm 0.06$ & $1.68 \pm 0.04$ \\
\hline 30 & $7.42 \pm 0.05$ & $7.03 \pm 0.06$ & $6.20 \pm 0.20$ & $0.63 \pm 0.03$ & $2.23 \pm 0.08$ & $2.19 \pm 0.03$ \\
\hline
\end{tabular}

Table 2. Changes of TOC and TN during vermicomposting of activated sludge.

\begin{tabular}{|c|c|c|c|c|c|c|}
\hline \multirow{3}{*}{ Days } & \multicolumn{3}{|c|}{ TOC (\%) } & \multicolumn{3}{|c|}{ TN (g/kg) } \\
\hline & \multirow{2}{*}{ Control } & \multicolumn{2}{|c|}{ Vermicomposting } & \multirow{2}{*}{ Control } & \multicolumn{2}{|c|}{ Vermicomposting } \\
\hline & & E. foetida & B. parvus & & E. foetida & B. parvus \\
\hline 0 & $32.32 \pm 2.32$ & $32.32 \pm 2.32$ & $32.32 \pm 2.32$ & $36.55 \pm 1.30$ & $36.55 \pm 1.30$ & $36.55 \pm 1.30$ \\
\hline 10 & $31.27 \pm 1.52$ & $29.16 \pm 2.31$ & $29.24 \pm 0.11$ & $36.87 \pm 1.09$ & $38.50 \pm 0.25$ & $37.99 \pm 0.69$ \\
\hline 20 & $29.67 \pm 0.91$ & $25.33 \pm 0.83$ & $26.26 \pm 0.35$ & $36.54 \pm 0.64$ & $43.87 \pm 0.90$ & $42.99 \pm 0.7$ \\
\hline 30 & $28.33 \pm 0.36$ & $23.59 \pm 2.22$ & $22.89 \pm 0.26$ & $35.37 \pm 0.71$ & $50.25 \pm 2.10$ & $49.48 \pm 0.12$ \\
\hline
\end{tabular}

Table 3. Changes of TP and TK during vermicomposting of activated sludge.

\begin{tabular}{|c|c|c|c|c|c|c|}
\hline \multirow{3}{*}{ Days } & \multicolumn{3}{|c|}{ TP (g/kg) } & \multicolumn{3}{|c|}{ TK (g/kg) } \\
\hline & \multirow{2}{*}{ Control } & \multicolumn{2}{|c|}{ Vermicomposting } & \multirow{2}{*}{ Control } & \multicolumn{2}{|c|}{ Vermicomposting } \\
\hline & & E. foetida & B. parvus & & E. foetida & B. parvus \\
\hline 0 & $7.70 \pm 0.13$ & $7.70 \pm 0.13$ & $7.70 \pm 0.13$ & $11.22 \pm 0.13$ & $11.22 \pm 0.13$ & $11.22 \pm 0.13$ \\
\hline 10 & $7.76 \pm 0.05$ & $7.98 \pm 0.17$ & $7.87 \pm 0.14$ & $11.56 \pm 0.20$ & $12.65 \pm 0.14$ & $12.42 \pm 0.34$ \\
\hline 20 & $8.05 \pm 0.07$ & $8.51 \pm 0.25$ & $8.31 \pm 0.23$ & $11.62 \pm 0.40$ & $12.78 \pm 0.51$ & $13.36 \pm 0.38$ \\
\hline 30 & $8.14 \pm 0.13$ & $9.16 \pm 0.52$ & $8.88 \pm 0.37$ & $12.02 \pm 0.39$ & $13.48 \pm 0.82$ & $14.80 \pm 0.59$ \\
\hline
\end{tabular}

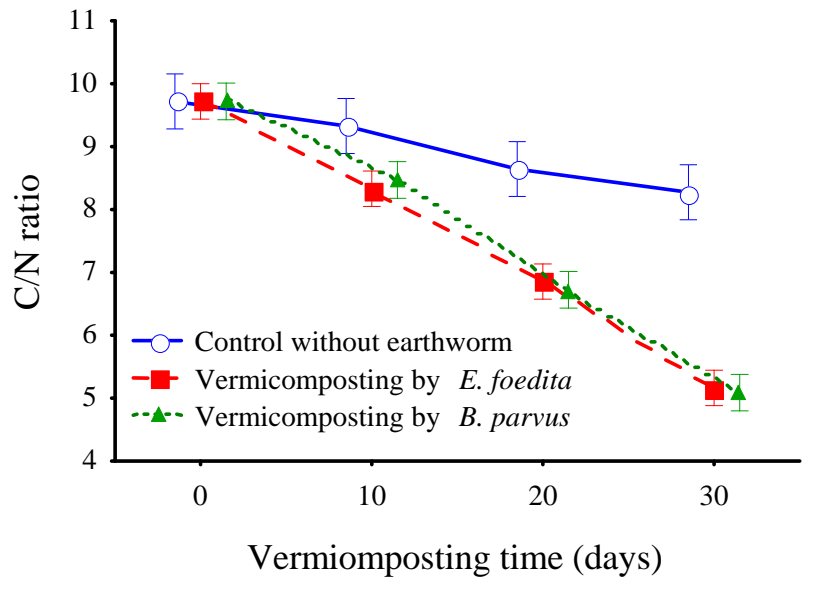

Figure 1. Change of $\mathrm{C} / \mathrm{N}$ ratio during vermicomposting.

found statistically insignificant $(p>0.05)$. The increase of TK during vermicomposting was also reported in existing literatures $[5,6]$. The enhanced release of $\mathrm{K}$ from the sludge due to the production of acids by microorganisms and the increased number of micro flora in the gut of earthworms is a likely reason behind the observed increases of $\mathrm{K}$ in the vermicast [10]. However, cautions should be addressed here since some researchers observed decreases in the content of $\mathrm{K}$, as a result of probable leaching of soluble potassium by the excess water content [17].

\subsection{Changes in Heavy Metals during Vermicomposting Process}

Heavy metals in the sewage sludge may come from a variety of sources like batteries, consumer electronics, ceramics, light bulbs, plastics, house dust and paint etc. If higher concentrations of heavy metals remain in the vermicast, they may cause detrimental effects upon the growth of plants. So, it is essential to trace the behaviour of heavy metals during vermicomposting. As shown in Figure 2, for all four targeted heavy metals $(\mathrm{Cu}, \mathrm{Zn}, \mathrm{Pb}$ and $\mathrm{Cr}$ ), dramatic decreases in their content occurred even if the decreasing extent was somewhat different: $\mathrm{Cu}$ decreased by $20.5 \%$, Zn by $15.0 \%$, Pb by $13.0 \%$ and $\mathrm{Cr}$ 
by $9.8 \%$ in the treatment systems with earthworms as against the control (for $\mathrm{Cu}, p<0.001$; for $\mathrm{Zn}, p<0.001$; for $\mathrm{Pb}, p<0.001$; for $\mathrm{Cr}, p<0.05)$. The differences in the content of these four metals in the end products of vermicomposting with both tested worm species were found less significant $(p>0.05)$. The decreases in the content of heavy metals were probably due to accumulation of these metals into the bodies of earthworms. In general, as decomposers for organic matters, many soil faunas like earthworms, enchytraeids and mites can ingest and digest organic compounds for their own metabolism. During the metabolic process, the decomposers inevitably accumulate a certain quantity of contaminants into their bodies and skins through direct or indirect adsorption and absorption [18,19]. Previous studies have revealed that, during vermicomposting, earthworms reduced a considerable amount of heavy metals from the substrate through bioaccumulation [11,14]. Earthworms ingest a large quantity of organic materials in order to achieve necessary nutrition and, during the process they can liberate metals into free forms as a result of enzymatic reaction in their gut [12]. The free forms of metals are then sorbed onto different organs such as chloragogenous cells, gizzard and connective tissues [20]. On the other hand, the results also suggested that different heavy metals exhibited different reductions during vermicomposting. The extent of reductions of heavy metals due to bioaccumulation of earthworms was found to be directly related to the availability and the initial levels of heavy metals in the substrate [12].

\subsection{Biology of Earthworms in Vermicomposting of Activated Sludge}

Vermicomposting is considered in terms of the biomass and the cocoon production of earthworms as well. As summarized in Table 4, earthworms showed a significant increase in the individual weight $(p<0.05)$ at the end.

E. foetida and $B$. parvus reached the mean individual weight of $808.9 \pm 45.4 \mathrm{mg}$ and $723.3 \pm 35.6 \mathrm{mg}$ after 30 days, respectively. Comparatively, the individual growth rate (mg/day) of $B$. parvus was slightly higher that of $E$. foetida; however, the difference between these two worms was statistically insignificant $(p>0.05)$. In a previous study, Suthar (2010b) [12] reported the growth rate of about $1.13-5.51 \mathrm{mg} /$ day and $1.44-2.50 \mathrm{mg} /$ day for $E$. foetida in vermicomposting of cow dung-amended sewage sludge and primary sludge, respectively. Similar to his result, a higher cocoon production (Table 4) with the tested two earthworm species in the present study was also observed; with the total cocoon production after 30 days of vermicomposting with E. foetida being ap- parently lower than that with $B$. parvus. The food availability and the stocking density in the vermicomposting system are important factors related to the growth rate and the cocoon production of earthworms $[6,12]$. Our results thus suggest that activated sludge without any pre-treatment and bulking materials remains palatable for earthworms in continuous vermicomposting systems. In the systems, the activity of populated microorganisms may play an important role in earthworms' diet, which makes organic matter much more palatable. In batch systems, however, as reported in previous studies [12-14], pre-treatment and bulking materials are essential to vermicomposting. This difference may be ascribed to the fact that these two different vermicomposting systems are associated with different operation methods, which may lead to differences in the patterns of earthworms' ingestion and organic matter decomposition. In regard of the mortality of E. foetida and B. parvus, an observable difference was existent as could be seen in Table 4; however, statistical analysis indicated that this difference was not significant $(p>0.05)$. The lower mortality of both earthworms indicates that the continuous vermicomposting systems investigated in the present study can produce a favourable environment condition for earthworms. In addition, it is also inferable that direct vermicomposting using vermicast as the substrate is a suitable technology for disposal of municipal activated sludge.

\section{CONCLUSION}

Direct vermistabilization of municipal activated sludge in the continuous system resulted in the drop of $\mathrm{pH}$ to 6.20 - 7.03, the increase of EC, total N, total P and total K by about 3.5 folds, $35.4 \%-37.5 \%, 15.4 \%-20.0 \%$ and $20.1 \%-31.9 \%$, and the decrease of TOC, C/N ratio and content of heavy metals for $\mathrm{Cu}, \mathrm{Zn}, \mathrm{Pb}$ and $\mathrm{Cr}$ by $27.0 \%$ - 29.2\%, $47.2 \%$ - 47.8\%, and 35.2\% - 37.7\%, 29.3\% $38.8 \%, 21.2 \%-27.4 \%$ and $17.0 \%-23.0 \%$, respectively, with the earthworm species of B. parvus and E. foetida, as compared to the results of the parallel control experiment. Moreover, the growth rate and the reproduction rate of $E$. foetida and B. parvus were able to reach 4.8 $5.8 \mathrm{mg} /$ day and $2.3-3.7$ cocoon/day, respectively. The results obtained from this study indicate that direct vermistabilization can enhance the nutritive value and reduce the phytotoxicity of end products, thus suggesting that direct vermistabilization by using vermicast as the substrate bedding could be a feasible technology for the management of municipal activated sludge.

\section{ACKNOWLEDGEMENTS}

This work was financially supported by the Natural Science Founda 
$\mathrm{Ln}$

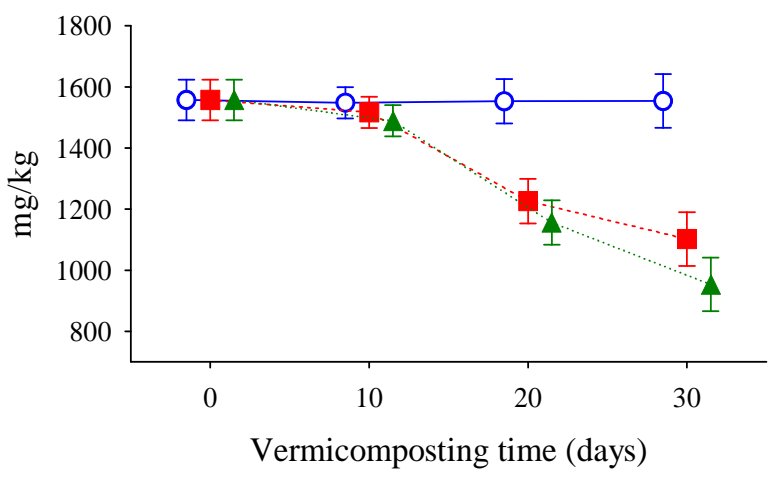

$\mathrm{Pb}$

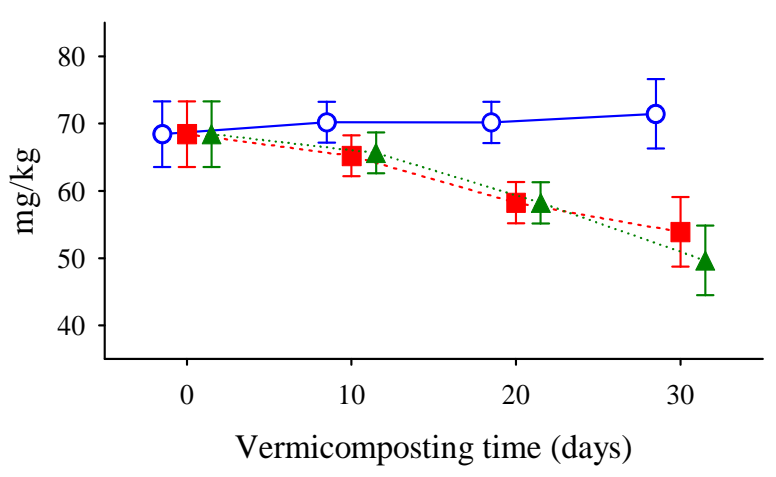

Ciu

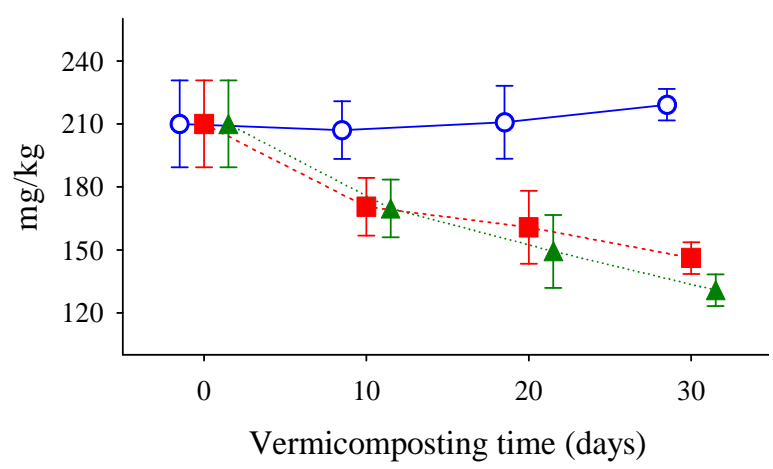

$\mathrm{Cr}$

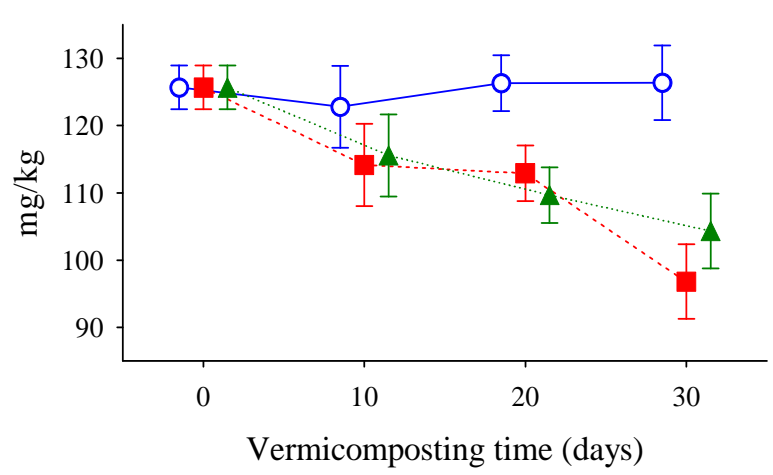

- -Control without earthworm - Vermicomposting by E. foetida - Vermicomposting by B. parvus

Figure 2. Changes of heavy metals contents during vermicomposting.

Table 4. Individual growth, cocoon production and mortality of E. foetida and B. parvus.

\begin{tabular}{|c|c|c|c|c|c|}
\hline \multirow{2}{*}{ Treatment } & \multicolumn{2}{|c|}{ Mean individual biomass (mg) } & \multirow{2}{*}{$\begin{array}{l}\text { Mean growth rate of } \\
\text { individual (mg/day) }\end{array}$} & \multirow{2}{*}{$\begin{array}{c}\text { Total cocoon production } \\
\text { after } 30 \text { days }\end{array}$} & \multirow{2}{*}{$\begin{array}{c}\text { Mortality after } 30 \\
\text { days (\%) }\end{array}$} \\
\hline & Start & End & & & \\
\hline E. foetida & $586.8 \pm 24.9$ & $808.9 \pm 45.4$ & $6.50 \pm 2.7$ & $144.3 \pm 16.2$ & $4.0 \pm 6.9$ \\
\hline B. parvus & $561.9 \pm 15.7$ & $723.3 \pm 35.6$ & $4.87 \pm 0.8$ & $95.7 \pm 6.5$ & $2.7 \pm 4.6$ \\
\hline
\end{tabular}

tion of China (NSFC, 51168029) and the Program of Gansu Provincial Science and Technology Department (1104FKCA157).

\section{REFERENCES}

[1] Dominguez, J. (2004) State-of-the art and new perspectives on vermicomposting research. In: Edwards, C.A. Ed., Earthworm Ecology, 2nd Edition, CRC Press, 401424. http://dx.doi.org/10.1201/9781420039719.ch20

[2] Ndegwa, P.M. and Thompson, S.A. (2001) Integrating composting and vermicomposting the treatment and bioconversion of biosolids. Bioresource Technology, 76, 107112. http://dx.doi.org/10.1016/S0960-8524(00)00104-8

[3] Hartenstein, R. (1981) Production of earthworms as a potentially economic source of protein. Biotechnology and Bioengineering, 23, 1797-1811. http://dx.doi.org/10.1002/bit.260230808

[4] Neuhauser, E.F., Loehr, R.C. and Malecki, M.R. (1988)
The potential of earthworms for managing sewage sludge. In: Edwards, C.A. and Neuhauser, E.F., Eds., Earthworms in Waste and Environmental Management. SPB Academic Publishing, The Hague, 9-20.

[5] Gupta, R. and Garg, V.K. (2008) Stabilization of primary sewage sludge during vermicomposting. Journal of Hazardous Materials, 162, 430-439.

http://dx.doi.org/10.1016/j.jhazmat.2007.09.055

[6] Khwairakpam, M. and Bhargava, R. (2009) Vermitechnology for sewage sludge recycling. Journal of Hazardous Materials, 161, 948-954.

http://dx.doi.org/10.1016/j.jhazmat.2008.04.088

[7] Suthar, S. (2010). Pilot scale vermireactors for sewage sludge stabilization and metal remediation process: Comparison with small-scale vermireactors. Ecological Engineering, 36, 703-712. http://dx.doi.org/10.1016/j.ecoleng.2009.12.016

[8] Hait, S. and Tare, V. (2011) Vermistablization of primary sewage sludge. Bioresource Technology, 101, 2812-2820. 
http://dx.doi.org/10.1016/j.biortech.2010.10.031

[9] Nelson, D.W. and Sommers, L.E. (1982) Total carbon and organic carbon and organic matter. In: Page, A.L., Miller, R.H. and Keeney, D.R., Eds., Method of Soil Analysis, American Society of agronomy, Madison, 539-579.

[10] Kaviraj and Sharma, S. (2003) Municipal solid waste management through vermicomposting employing exotic and local species of earthworms. Bioresource Technology, 90, 169-173. http://dx.doi.org/10.1016/S0960-8524(03)00123-8

[11] Suthar, S. and Singh, S. (2008) Feasibility of vermicomposting in biostabilization of sludge from a distillery industry. Science of the Total Environment, 394, 237-243. http://dx.doi.org/10.1016/j.scitotenv.2008.02.005

[12] Suthar, S. (2010). Recycling of agro-industrial sludge through vermitechnology. Ecological Engineering, 36, 1028-1036. http://dx.doi.org/10.1016/j.ecoleng.2010.04.015

[13] Garg, P., Gupta, A. and Satya, S. (2006) Vermicomposting of different types of waste using Eisenia foetida: A comparative study. Bioresource Technology, 97, 391-395. http://dx.doi.org/10.1016/j.biortech.2005.03.009

[14] Suthar, S. (2009) Vermistabilization of municipal sewage sludge amended with sugarcane trash using epigeic Eisenia fetida (Oligochaeta). Journal of Hazardous Materials, 163, 199-206. http://dx.doi.org/10.1016/j.jhazmat.2008.06.106

[15] Lee, K.E. (1992) Some trends opportunities in earthworm research or: Darwin's children. The future of our discipline. Soil Biology \& Biochemistry, 24, 1765-1771. http://dx.doi.org/10.1016/0038-0717(92)90185-Z

[16] Le Bayon, R.C. and Binet, F. (2006) Earthworm changes the distribution and availability of phosphorous in organic substrates. Soil Biology \& Biochemistry, 38, 235-246. http://dx.doi.org/10.1016/j.soilbio.2005.05.013

[17] Sangwan, P., Kaushik, C.P. and Garg, V.K. (2008) Vermiconversion of industrial sludge for recycling the nutrients. Bioresource Technology, 99, 8699-8704. http://dx.doi.org/10.1016/j.biortech.2008.04.022

[18] Haimi, J. (2000) Decomposer animals and bioremediation of soils. Environmental Pollution, 107, 233-238. http://dx.doi.org/10.1016/S0269-7491(99)00142-6

[19] Curry, J.P. and Schmidt, O. (2007) The feeding ecology of earthworms-A review. Pedobiologia, 50, 463-477. http://dx.doi.org/10.1016/j.pedobi.2006.09.001

[20] Vijver, M.G., Wolterbeek, H.T., Vink, J.P.M. and Van Gestel, G.A.M. (2005) Surface adsorption of metals onto the earthworm Lumbricus rubellus and the isopod Porcellio scaber is negligible compared to absorption in the body. Science of the Total Environment, 340, 271-280. http://dx.doi.org/10.1016/j.scitotenv.2004.12.018 